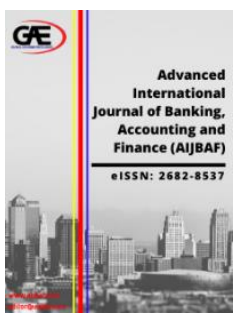

\author{
ADVANCED INTERNATIONAL JOURNAL OF \\ BANKING, ACCOUNTING AND FINANCE \\ (AIJBAF) \\ WWW.aijbaf.com
}

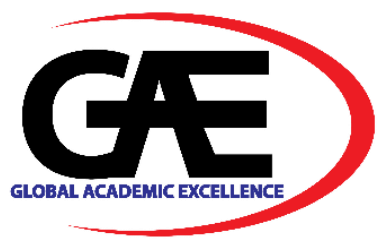

\title{
CORPORATE GOVERNANCE AND FIRM PERFORMANCE IN DEVELOPING COUNTRIES: EVIDENCE FROM EAST AFRICA
}

\author{
David Namanya ${ }^{1 *}$, Fong, Michelle Wye Leng ${ }^{2}$, Jude Thaddeo Mugarura ${ }^{3}$ \\ 1 Department of Accounting and Finance, Makerere University, Kampala, Uganda \\ Email: namanyandb@gmail.com and david.namanya@mak.ac.ug \\ 2 Victoria University Business School, Melbourne, Australia \\ Email: Michelle.Fong@vu.edu.au \\ 3 Department of Marketing and Management, Makerere University, Kampala, Uganda \\ Email: mugarurajude@gmail.com \\ Corresponding Author
}

\section{Article Info:}

\section{Article history:}

Received date: 01.06.2021

Revised date: 15.06 .2021

Accepted date: 25.06.2021

Published date: 30.06 .2021

\section{To cite this document:}

Namaya, D., Fong, M. W. L., \& Mugarura, J. T. (2021). Corporate Governance And Firm Performance In Developing Countries: Evidence From East Africa. Advanced International Journal of Banking, Accounting, and Finance, 3 (7), 127147.

DOI: $10.35631 / A I J B A F .370011$

This work is licensed under CC BY 4.0

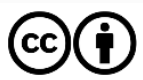

\begin{abstract}
:
The main purpose of this study was to examine the relationship between corporate governance and firm performance; compare the influence of corporate governance on firm performance before and after the operationalization of the EAC-Common Market in 2010 and make recommendations about corporate governance codes that enhances firm performance. We adopted a positivist paradigm in a quantitative analysis using non-probability sampling to select forty-two EAC-listed companies. Hypothesizes were developed from literature review and secondary data from academic databases and annual reports was extracted and analysed using SPSS version 23 to generate descriptive statistics, correlation, and regression output. Our findings revealed that gender diversity of the board and enterprise risk management had no significant influence on firm performance but the relationship between board independence, the board size, and firm performance was inconclusive. On the changes in corporate governance indicators before and after the operationalization of the EAC Common Market in 2010, we discovered insignificant changes nevertheless, the results from regression model fit revealed that the indicators become relatively more relevant to company financial performance after the operationalization of the EAC Common Market in 2010 than before.
\end{abstract}

Keywords:

Corporate Governance, Firm Performance, Gender Diversity, Board Size And Enterprise Risk Management 
Volume 3 Issue 7 (June 2021) PP. 127-147 DOI 10.35631/AIJBAF.370011

\section{Introduction}

The recent past has seen many corporate failures in the East African Community (EAC) mainly due to inept governance practices often characterized by corruption, exploitation and nepotism (Brownbridge 2002; Fulgence 2014). This culminated into poor performance and corporate failure such as the collapses of the Trust Bank Uganda in 1999, the Euro Bank in 2003 and Daima Bank in 2005. These banks became insolvent due to poor internal control systems and lack of good governance, pronounced by enormous inside lending to directors and shareholders (Cheserek 2007). In Tanzania, the closure of the Richmond Development Company, Kiwira and Meremeta mining company, Dowans electricity company and EPA were due corruption scandals causing a big loss to their shareholders (Fulgence 2014). Uganda was never spared, three private commercial banks, namely International Credit Bank, Greenland Bank and Trust Bank had to closed indefinitely in 1999 following a court ruling that implicated the management for corruption. These failures prompted EAC governments and their regulatory authorities to introduce new laws and codes of governance to protect all stakeholders' interest (Muriithi 2009). Until late 1990s, the codes of corporate governance and good practices were not seen as important by both the investors and the government regulatory agencies (Munisi \& Randoy 2013). Instead, the EAC governments acting as company regulatory agents put more emphasis on the company law as a means to mitigate 'principal-agent conflict'. There was a lot of emphasis on the strict enforcement of company laws seen as a suitable means of reducing inside dealing and market speculations. Moreover, the EAC had relatively laws and regulations to protect the interests of different stakeholders (Rossouw 2005). These challenges imposed a profound pressure on the EAC countries to improve their corporate governance, which has resulted in the present corporate governance framework in the EAC, which emphasizes protection of shareholder interests, enhanced investor confidence and capital market development (Gakeri 2013). The EAC developed their corporate governance codes of governance based on the UK, Malaysia, South Africa and the Commonwealth Association for Corporate governance (CWACG) as the major benchmarks (CMA, K 2002; CMA, U 2003).

The main aim of our study was to examine the influence of corporate governance on firm performance within the EAC by addressing the following specific objectives: examine the relationship between corporate governance and firm performance in EAC, compare the influence of Corporate governance on firm performance before and after the operationalization of the EAC- Common Market in 2010, and make recommend any corporate governance codes that enhances firm performance. Corporate Governance amongst the EAC member countries is highly regarded as a means to acceleration of the EAC's integration (EAC 2015), because presence of a good governance framework, helps in protecting the investors' interests (Berglof \& Claessens 2004), which enables companies to consolidate the benefit from the EAC integration progress, such as increased cross-listing of companies, intra-trade among the EAC member states and reduction in cargo movement times (Prinsloo, 2013). Although there is evidence of some economic developments due to the current economic integration, only Kenya has amended its corporate governance and code governance to reflect the changes brought about by the EAC integration. This research is therefore significant in exploring the necessary changes in corporate governance following the recent developments in the EAC economic integration and will suggest recommendations that can be used to inform corporate governance policy changes within the EAC. We therefore based our study on the need to appraise the current EAC corporate government elements in consideration of the changes that have been brought about by the EAC's economic transformation from a Customs Union (with zero tariff 
Volume 3 Issue 7 (June 2021) PP. 127-147

DOI 10.35631/AIJBAF.370011

barriers) in 2005 to the current Common Market (with free movement of capital and labor) which started in July 2010.

\section{Literature Review}

We adopted the agency theory as commonly used in corporate governance and company performance studies (McGrath \& Whitty 2015; Nguyen et al., 2015; Zeitoun \& Pamini 2015).

\section{The Agency Theory}

According to this theory, the need to separate organizational ownership and control creates an agency relationship, whereby shareholders (principals) contract managers (agents) to run their business on their behalf (Bhaduri \& Selarka 2016; Fama \& Jensen 1983; Jensen \& Meckling 1976). An agency relationship is thus established due to an organisation's need to ensure independence of organisational control from organisational ownership. Jensen and Meckling (1976) perceive a company as a nexus between different types of stakeholders, with the principal at one end and an agent on the other. The principal and the agent hence have different rights and responsibilities, which theoretically should complement each other for the economic good of the company. However, the agency theory suggests that managers are selfish beings, inclined to the promotion of personal interests rather than those of the principal, in the process of the company's strategic decision-making. The agency theory hence seeks to resolve such principal-agent conflicts of interest by means of applying strict monitoring and control systems, which aim to restrain subjective management decisions and actions. The principalagent conflict is further exacerbated by information asymmetry, in that an agent is perceived to have more information than that of the principal, thus creating a moral dilemma which might motivate an agent to pursue personal interests that may be irreconcilable with those of the principal (Bhaduri \& Selarka 2016). Consequently, the principal is forced to incur agency costs, e.g. the monitoring cost (audit fees) to make the agents accountable for their decision-making roles, in an attempt to reduce the agent's extravagances that may harm the principal's economic interests (Jensen \& Meckling 1976).

Typically, in listed companies, shareholders appoint a board of directors (agents) to oversee the company on their behalf. The directors, in turn, engage employees to carry out the day-today management of company undertakings. The shareholders delegate their powers to the agents, imposing on them a fiduciary duty to serve the interests of the shareholders. Shareholders appoint agents to run their business because some companies have hundreds if not thousands of shareholders; it would be impracticable, indeed hectic, if every shareholder wanted to run the business. Moreover, most shareholders lack the skills, knowledge, time or inclination to manage their own investments (Bhaduri \& Selarka 2016). They are therefore willing to engage a professional manager with the skills and knowledge needed to achieve the company's primary objectives of shareholder's wealth maximisation (Friedman 2007). Agents, on the other hand, are willing to offer their skills, knowledge and time in exchange for reward, in pecuniary or nonpecuniary terms. This creates multiple goals, and/or lack of goal congruence between the agent and the principal (Jensen \& Meckling 1976). It is in the principal's interest to minimise company costs, including the manager's rewards, to maximise the company value, but the agents' essentially selfish nature naturally inclines them to maximise their personal interests too, by way of better employment privileges, which might include salary increments, luxurious offices, personal assistants or even luxury cars. Consequently, agents might not always act in the best interests of the principal, but rather seek to maximise their own utility, which gives rise to principal-agent conflicts (Jensen \& Meckling 1976). To mitigate such Copyright (C) GLOBAL ACADEMIC EXCELLENCE (M) SDN BHD - All rights reserved 
Volume 3 Issue 7 (June 2021) PP. 127-147

DOI 10.35631/AIJBAF.370011

conflicts, the principal must incur some costs, such as the expense of making contracts that define the manager's accountability and responsibility, payments for asymmetric information (managers being better informed about the company performance and future prospects), and payments for monitoring of managerial performance e.g. paying for external audits and review (Bhaduri \& Selarka 2016; Fama \& Jensen 1983; Jensen \& Meckling 1976).

Furthermore, the principal will also need to ensure that an appropriate reward scheme is implemented, namely one which effectively motivates the agent to act in the principal's best interest. Such initiatives result in additional monitoring costs aimed at linking the agent's selfish nature to the principal's best interests, thus incentivising a reduction in the agent's excessive expenditures, whilst encouraging the achievement of higher shareholder returns in the long run. The agency theory, hence advocates strict monitoring and control of the agent's activities, which can be achieved by putting in place a set of good corporate governance policies and structures, such as utilisation of a suitable board structure, composed of an appropriate number of independent non-executive directors and board diversity, as well as good risk management systems as a means of increasing the principal's wealth (Grant \& McGhee 2014). We used the agency theory recommendations to explain the importance of gender diversity of the board, board independence, risk management and board size as means of enhancing company financial performance.

\section{Hypothesis Development}

Our hypotheses rest on the broad assumption that the adoption of corporate governance and codes of best practices is likely to enhance company financial performance (Shleifer \& Vishny 1997).

\section{Gender Diversity of the Board}

A number of investigations in the past have suggested a positive relationship between gender diversity of the board and company financial performance. For instance, Ford and Richardson (1994) posit that female directors are naturally more ethically upright than their male counterparts, especially in managing finances. Broadbridge et al., (2006), and Konrad et al,. (2008) argue that female directors are more organized than their male counterparts which improves company monitoring and controls leading to the enhancement of company financial performance. According to Khan and Vieito, (2013), females are more risk-averse than men, hence companies with female directors are less likely to take high risks on investment or diversification, which may increase agency costs and reduce company value (Niessen \& Ruenzi 2006; Vandegrift \& Brown 2005). Gender diversity was measured as the ratio of female directors to total directors as a measure of gender diversity of the board and hence adopted the following hypothesis to test the influence of gender diversity on a company's financial performance. There is a significant relationship between gender diversity of the board and company financial performance $\left(\mathrm{H}^{1}\right)$.

\section{Board Independence}

The choice of the board independence variable in wewas based on the assumption that board independence enhances a board's monitoring capacity, hence it was deemed useful to analyze the extent to which it may or may not influence the EAC-listed companies' financial performance. We measured board independence as the ratio of non-executive directors to total directors (Anderson \& Reeb 2003; Barontini \& Caprio 2006). We thus hypothesize that: 
Volume 3 Issue 7 (June 2021) PP. 127-147

DOI 10.35631/AIJBAF.370011

There is a significant relationship between board independence and company financial performance $\left(\mathrm{H}^{2}\right)$.

\section{Enterprise Risk Management (ERM)}

According to Shleifer and Vishny (1997), corporate governance provides a good framework for risk management and can help in the enhancement of shareholder return on investment. Indeed, ERM has been found to be a source of strategic strengthening for retail companies in the UK (Woods 2007). According to Lundqvist (2015), companies worldwide have adopted ERM as part of their corporate governance and good practice by the creation of either a board risk committee or a chief risk officer position, or both, to manage the company's combined risks. Hence, ERM is considered as one way of enhancing company performance because it helps to avoid reputational costs, losses and, at worst, company bankruptcy (Gordon et al.,2009; Pagach \& Warr 2011). The adoption of ERM also helps the company management to improve their decision-making practices (Grace et al., 2015; Nocco \& Stulz 2006) and resource allocation (Baxter et al., 2013; Hoyt \& Liebenberg 2011). To test the influence of ERM on company financial performance, we hypothesize that:

There is a significant relationship between company commitment to enterprise risk management and its financial performance. $\left(\mathrm{H}^{3}\right)$.

\section{Board Size}

According to Conyon and Peck (1998), there is a negative relationship between a larger board and company performance, because large boards are associated with the 'free rider' problem where board members play a passive role in monitoring and supervision thus slowing down decision-making process and hampering the companies' financial performance (Conyon \& Peck 1998). According to Jensen, M. C. (1993), a smaller board is more cohesive and easier to control than large ones while Eisenberg, (2005) discovered a negative relationship between large board size and company performance because it leads to lack of board cohesion and Nguyen et al., (2015), posits that large boards tend to be associated with agency costs, which leads decline in company value. The current study measured board size as the total number of directors. We derived the following hypothesis

There is a significant relationship between the board size and the company financial performance $\left(\mathrm{H}^{4}\right)$.

Changes in corporate governance indicators before and after EAC Common Market The establishment of the EAC-Common Market in 2010 led to the regional harmonization of trade, taxation regimes, accounting systems, and security market listings rules within the region (Yabara 2012). Other fundamental changes brought about by the operationalization of the EAC- Common Market is the free movement of capital and labor among the member states. This free movement of factors of production within the region have affect current corporate governance structures in the EAC and hence the need for changes in corporate governance and good practice. Other changes brought about by the operationalization of the EAC-Common Market included an increase in the number of cross-listed companies within the EAC Security Markets where companies wishing to raise capital on any of the EAC's stock exchanges have to comply with the capital market requirements of that specific stock exchange, including the code of corporate governance. To identify any changes in the study's corporate governance indicators since the operationalization of the EAC common market, we hypothesize that:

There has been a significant change in corporate governance indicators following the operationalization of the EAC- Common Market in $2010\left(\mathrm{H}^{5}\right)$.

Copyright $\odot$ GLOBAL ACADEMIC EXCELLENCE (M) SDN BHD - All rights reserved 


\section{Research Methodology}

To achieve our study objectives, we adopted the positivist paradigm in deductive approach, using quantitative methods to identify the causes and effects of social phenomena (Collis \& Hussey 2013). We used the quantitative method as often used in corporate governance and company performance studies (Alagha 2016; Heenetigala 2011; Waduge 2011). With deductive approach, we developed our hypotheses from existing literature, and data was collected and used to confirm or negate the suggested hypotheses. We based our hypothesis testing on secondary data from database statistics and annual reports. The use of a deductive approach and hypothesis testing method is a consistent with a quantitative research (Gill and Johnson, 2010) and was therefore adopted due to its advantages over the qualitative approach. For example, the use of statistical measurement in the quantitative approach makes it easier for researchers to analyze and present results for explanatory purposes. Additionally, the quantitative method has less prejudice error than the qualitative approach (Collis \& Hussey 2013). According to Veal (2005), a qualitative approach does not often offer researchers with the same level of rigor as a quantitative approach. We obtained our quantitative data from secondary sources, which is the most commonly used source for obtaining data in most business finance, accounting and company performance research studies (Adams, Hermalin \& Weisbach 2008; Alagha 2016; Heenetigala 2011; Klein 1998; Waduge 2011). Our choice of secondary data was thus based on its appropriateness in addressing the above-mentioned aims of this study.

\section{Data Collection}

We used secondary data because it was inexpensive to collect than primary data. Moreover, the collection and transformation of primary data requires a long timeframe than secondary data. The use of secondary data is also consistent with other accounting, finance and corporate governance research studies where researchers clearly stated that they used secondary data to save time and money (Beasley, 1996; Heenetigala 2011; Ngwenya \& Khumalo 2012; Okiro 2014; Waduge 2011). The type of secondary data sources used for literature review on corporate governance and company financial performance includes e-books, press releases, journal articles and websites. We acquired financial data from well-established databases such as Orbis Bureau Van Dijk, DataStream, Eikon and Mint Global Bureau Van Dijk. Supplementary corporate governance data sources, such as published companies' annual reports and company websites, were also used in this studdy. Microsoft Excel and Statistical Package for the Social Science (SPSS) version 23 were used for data handling and analysis. Excel was used for managing and formatting the data before exporting it into SPSS for statistical analysis. SPSS was used to carry out correlation, and linear regression analyses. According to Field (2009), SPSS is capable of providing comprehensive outputs for analyses such as descriptive statistics, model analysis, multiple regressions and correlation analysis.

We adopted non-probability sampling to select the forty-two listed companies used in the current study. Listed companies were preferred because unlike private companies, their information is publicly available and they tend to provide the information necessary to identify their corporate governance structures (Okiro, 2014). We initially intended to use as a population all the listed companies on the EAC Security Markets in 2008/2009 and 2013/2014. A total of 108 companies were listed on the EAC Security Markets as at 31st June 2014. These included sixty-six companies listed on the NSE, twenty-one companies on the DSE, sixteen companies on the USE, and five companies on the RSE. However, not all the listed companies qualified to be included in the sample. Sixty-six EAC listed companies were excluded either Copyright $($ C GLOBAL ACADEMIC EXCELLENCE (M) SDN BHD - All rights reserved 
Volume 3 Issue 7 (June 2021) PP. 127-147

DOI 10.35631/AIJBAF.370011

because they were not listed on the EAC stock market for the full financial years 2008/2009 and 2013/2014, or because their annual reports were not available from the DataStream, Eikon and Mint Global Bureau Van Dijk databases.

\section{Dependent Variables}

We adopted four dependent variables comprised of accounting-based measures (ROE and ROA), and market-based measurements (TBQ and PER). According to Kaplan and Norton (1996) using mixed performance indicators helps to neutralize the shortcomings of a single measurement method, hence we adopted a mix to overcome the above weaknesses.

\section{Control Variables}

According to Bowerman et al., (2003), a control variable is a variable which is held constant during an experiment to assess or clarify changes in other independent variables. We adopted total assets and market capitalization as our control variables to examine the statistical relationship between corporate governance and company performance. Market capitalization was computed by multiplying the year-end market price per share by the total number of outstanding shares at the year-end (Heenetigala 2011). Market capitalization represents the value of a company based on its perceived future economic prospects, and it is often used in corporate governance studies as a control variable (see Alagha 2016; Heenetigala 2011). The total assets represent the book value of all company assets at the year-end. Prior studies of corporate governance and company performance have used total assets as the control variable (Alagha 2016; Pathan et al., 2007).

\section{Regression Model}

According to Zikmund et al., (2012), the OLS regression is considered a straightforward method of statistical analysis which guarantees that a significant straight line result will produce least possible total error in using $\mathrm{X}$ to predict $\mathrm{Y}$. The OLS model was derived using equation below:

$\mathrm{Yi}=\beta \mathrm{o}+\beta 1 \mathrm{X}+\mathcal{E}$

Where: $\mathrm{Yi}=$ the dependent variable, $\mathrm{X}=$ the independent variable, $\beta 0=$ intercept, $\beta 1=$ slope and $\mathcal{E}=$ error term. The above equation was used to derive equation 2 and the subsequent four equations that were used in this study.

$\mathrm{Yt}=\beta \mathrm{o}+\beta 1 \mathrm{~GB}+\beta 2 \mathrm{BI}+\beta 3 \mathrm{RM}+\beta 4 \mathrm{BS}+\beta 6 \mathrm{LnTA}+\beta 7 \mathrm{LnMC}+\varepsilon \mathrm{t}$

1.

Where, $\beta 0=$ intercept, $\beta i=$ slope, where $\mathrm{i}$ is $1,2,3$ or 4 , Yt represents dependent variable (PER, TBQ, ROE or ROA) at time ' $\mathrm{t}$ ', $\mathrm{GB}=$ Gender diversity of the board, $\mathrm{BI}=$ Board independence, $\mathrm{RM}=$ Enterprise risk management, $\mathrm{BS}=$ Board size, $\mathrm{TA}=$ Total assets, $\mathrm{MC}=$ Market capitalization, and Et represents the margin of error due to other factors outside the model that may influence Yt.

We thus derived the following four model equations used to test the study hypotheses with the help of SPSS version 23.

$\begin{array}{ll}\mathrm{ROAt}=\beta \mathrm{o}+\beta 1 \mathrm{~GB}+\beta 2 \mathrm{BI}+\beta 3 \mathrm{RM}+\beta 4 \mathrm{BS}+\beta 6 \mathrm{TA}+\beta 7 \mathrm{MC}+\varepsilon \mathrm{t} & 3 \\ \mathrm{ROEt}=\beta \mathrm{o}+\beta 1 \mathrm{~GB}+\beta 2 \mathrm{BI}+\beta 3 \mathrm{RM}+\beta 4 \mathrm{BS}+\beta 6 \mathrm{TA}+\beta 7 \mathrm{MC}+\varepsilon \mathrm{t} & 4 \\ \mathrm{TBQt}=\beta \mathrm{o}+\beta 1 \mathrm{~GB}+\beta 2 \mathrm{BI}+\beta 3 \mathrm{RM}+\beta 4 \mathrm{BS}+\beta 6 \mathrm{TA}+\beta 7 \mathrm{MC}+\varepsilon \mathrm{t} & 5 \\ \mathrm{PERt}=\beta \mathrm{o}+\beta 1 \mathrm{~GB}+\beta 2 \mathrm{BI}+\beta 3 \mathrm{RM}+\beta 4 \mathrm{BS}+\beta 6 \mathrm{TA}+\beta 7 \mathrm{MC}+\varepsilon \mathrm{t} & 2\end{array}$ 


\section{Research Results}

\section{Descriptive Statistics}

Table 1 below presents the mean, median, maximum, minimum and standard deviation to identify the statistical characteristics of the dependent, independent and control variables.

Table 1. Descriptive Statistics

\begin{tabular}{|c|c|c|c|c|c|c|c|}
\hline & No & Mean & Median & Std. Dev. & Minimum & Maximum & Years \\
\hline $\operatorname{ROA}(\%)$ & 42 & 40.581 & 40.109 & 4.263 & 32.758 & 50.570 & \multirow{10}{*}{ 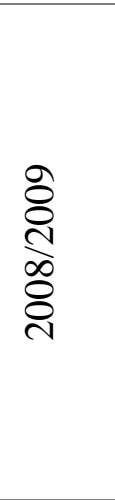 } \\
\hline ROE (\%) & 42 & 40.793 & 41.740 & 10.007 & 19.343 & 62.396 & \\
\hline TBQ & 42 & 0.425 & 0.390 & 1.913 & 0.165 & 2.038 & \\
\hline PER & 42 & 9.743 & 9.812 & 1.884 & 2.719 & 37.341 & \\
\hline $\mathrm{GB}(\%)$ & 42 & 10.621 & 10.000 & 10.138 & 00.000 & 30.000 & \\
\hline $\mathrm{BI}(\%)$ & 42 & 76.869 & 81.818 & 14.549 & 33.333 & 91.667 & \\
\hline $\mathrm{RM}$ & 42 & 0.189 & 00.000 & 0.397 & 00.000 & 1.000 & \\
\hline BS & 42 & 8.622 & 9.000 & 2.419 & 4.000 & 13.000 & \\
\hline TA (US\$) & & $185,944.6$ & $226,493.2$ & 5.5 & $5,590.6$ & $3,387,087.0$ & \\
\hline MC (US\$) & & 51,200 & 68,000 & 5.0 & 3,000 & 747,000 & \\
\hline ROA (\%) & 42 & 40.009 & 39.083 & 9.085 & 19.105 & 63.863 & \multirow{10}{*}{ 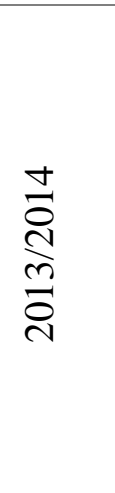 } \\
\hline ROE (\%) & 42 & 39.229 & 41.318 & 11.497 & 7.090 & 64.121 & \\
\hline TBQ & & 0.466 & 0.441 & 3.107 & 0.056 & 6.936 & \\
\hline PER & & 11.056 & 11.364 & 2.058 & 1.766 & 52.375 & \\
\hline GB (\%) & 42 & 15.737 & 15.385 & 13.897 & 0.000 & 50.000 & \\
\hline $\mathrm{BI}(\%)$ & 42 & 76.106 & 80.909 & 15.551 & 33.333 & 93.333 & \\
\hline RM & 42 & 0.119 & 0.000 & 0.328 & 0.000 & 1.000 & \\
\hline BS & 42 & 9.262 & 9.000 & 2.777 & 5.000 & 15.000 & \\
\hline TA (US\$) & & $182,816.7$ & $205,616.1$ & 6.4 & $5,280.8$ & $4,877,776.9$ & \\
\hline MC (US\$) & & 85,500 & 85,700 & 5.3 & 24,000 & $2,474,100$ & \\
\hline
\end{tabular}

Where: $\mathrm{GB}=$ Gender diversity of the board, $\mathrm{BI}=$ Board independence, $\mathrm{RM}=$ Enterprise Risk Management, $\mathrm{BS}=$ Board size, $\mathrm{TA}=$ Total assets, $\mathrm{MC}=$ Market capitalisation

Source: Own Source

\section{Return On Assets (ROA)}

Results of 2008/2009 descriptive statistics (Table 1) on ROA, indicates a mean of $40.58 \%$, median of $40.11 \%$, standard deviation of 4.26 , minimum of $32.76 \%$ and maximum of $50.57 \%$. For $2013 / 2014$, the mean ROA was $40.01 \%$, median $39.08 \%$, standard deviation 9.09 , minimum $19.11 \%$ and maximum $63.86 \%$. There is a positive mean value in both periods, which indicates that the EAC-listed companies on average generated a similar positive return of about $40 \%$ on assets for their shareholders before (2008/2009) and after (2013/2014) the operationalization of the EAC-Common Market. Despite a wider variation (standard deviation) in ROA among companies in 2013/2014. The degree of volatility in ROA increased by more than $50 \%$ in 2008/2009, as compared to 2013/2014. Comparatively, ROA was less volatile before the operationalization of the EAC Common market in 2010. 
Volume 3 Issue 7 (June 2021) PP. 127-147 DOI 10.35631/AIJBAF.370011

Return On Equity (ROE)

Analysis of 2008/2009 descriptive statistics on ROE in Table 1 indicated a mean of $40.79 \%$, median of $41.74 \%$, standard deviation of 10.01 , minimum of $19.34 \%$, and the maximum of $63.40 \%$. The ROE mean and median values for both 2008/2009 and 2013/2014 indicate that the EAC-listed companies in wegenerated a similar average positive return of about $40 \%$ for their shareholders before (2008/2009) and after (2013/2014) the establishment of the EACCommon Market.

\section{Tobin's $Q$ Ratio (TBQ)}

The TBQ descriptive statistics results in Table 1 show that for 2008/2009, TBQ had a mean of 0.4251 , median of 0.390 , standard deviation 1.913 , minimum of 0.165 , and maximum of 2.038 . For 2013/2014, the TBQ descriptive statistic results included a mean of -0.466 , median of 0.441 , standard deviation of 3.107 , minimum of 0.056 and maximum of 6.936 . The TBQ ratio is below 1, which means that the company's market value is lower than its value of total assets, suggesting that the company market value is undervalued (Chorafas, 2004). The degree of volatility in TBQ increased by $62 \%$ in $2013 / 2014$ as compared to $2008 / 2009$.

\section{Price Earnings Ratio (PER)}

The descriptive statistics results for 2008/2009 indicate an PER mean of 9.743, median of 9.812, standard deviation of 1.884 , minimum of 2.719 , and maximum of 37.34 . On the other hand, in 2013/2014, the descriptive statistic results for PER showed a mean of 11.056, median of 11.364, standard deviation of 2.058, minimum of 1.766, and maximum of 52.375. The PER's positive means and medians for both 2008/2009 and 2013/2014 are an indication that the EAClisted companies continued to create value for their shareholders after the operationalization of the EAC-Common Market in 2010.

\section{Gender Diversity of the Board (GB)}

According to the 2008/2009 descriptive statistics (Table 1), GB had a mean of $10.6 \%$, median of $10.0 \%$, standard deviation of 10.1 , minimum of $0 \%$ and maximum of $30 \%$. In 2013/2014, the mean GB of the board was $15.7 \%$, with a median of $15.4 \%$, standard deviation of 13.9 , minimum of $0 \%$ and maximum of 50\%. Table 1 also indicates that between 2008/2009 and $2013 / 2014$, the mean and median GB grew by $48 \%$ and $54 \%$ respectively, while the maximum GB increased from $30 \%$ to $50 \%$. This shows that there were more female directors on the board following the operationalization of the EAC-Common Market in 2010 than before.

\section{Board Independence (BI)}

Our results for 2008/2009 (table 1), BI with a mean value of $76.87 \%$, median of $81.82 \%$, standard deviation of 14.55 , minimum of $33.33 \%$ and maximum of $91.67 \%$. In 2013/2014, the mean BI was $76.11 \%$, the median was $80.91 \%$, the standard deviation was 15.55 , the minimum BI remained at $33.33 \%$ and the maximum was $93.33 \%$ (Table 1). Analysis of the results in Table 1 above, also indicates that the majority of companies in the EAC had more external than internal directors on their boards. The reason for the minimum board independence of $33.33 \%$ in the study data is that the corporate governance codes in all the EAC countries recommend that at least one-third of directors should be non-executive directors (CMA, K 2002; CMA, U 2003). Hence, the $33.33 \%$ minimum percentage for BI in 2008/2009 and 2013/2014 (Table 1) demonstrate that all companies maintained the degree of BI recommended by the EAC's code of governance and good practice. 
Volume 3 Issue 7 (June 2021) PP. 127-147 DOI 10.35631/AIJBAF.370011

\section{Enterprise Risk Management (RM)}

In this study, a company's adoption of RM management was represented by the existence of a chief risk officer and an audit and risk management committee of the board (Liebenberg \& Hoyt 2003). A dummy variable zero represents the presence of a chief risk officer only, while one represents the existence of a chief risk officer and an audit and risk management committee of the board. All companies used in wehad an audit and risk management committee. However, very few companies had a chief risk officer or any designated senior manager responsible for risk management as part of their risk management policy. The descriptive statistics (Table 1) indicated a decline in the mean RM from $18.90 \%$ to $11.90 \%$ following the operationalization of the EAC-Common Market in 2010. The standard deviation also decreased by 0.07 from 0.40 to 0.33 between 2008/2009 and 2013/2014.

\section{Board Size (BS)}

The descriptive statistics (Table 1) demonstrate that in 2008/2009, the mean and median BS was 8.62 and 9.0 respectively, the standard deviation was 2.42 , the minimum was 4.0 and the maximum was 13.0. In 2013/2014, the mean BS was 9.26, the median was 9.00, the standard deviation was 2.78, the minimum was 5.0 and the maximum was 15.0. Overall, after the operationalization of the EAC-Common market, the mean, minimum and maximum BS increased by $7 \%, 25 \%$ and $15 \%$ respectively. Available data also indicates that the listed companies in the EAC had an average BS of 9 directors, which is consistent with the optimal BS recommended by Lipton and Lorsch (1992).

\section{Total Assets (TA)}

The descriptive statistics (Table 1) for 2008/2009 show a mean of TA of US\$ 185, 944, median of US\$226, 493, and standard deviation of 5.5. The minimum of TA was US\$ 5, 591 with a maximum of US\$3, 387, 087. In 2013/2014, the mean of TA was US\$182, 817, the median was US\$ 205, 616, the standard deviation was 6, the minimum was US\$ 5, 281 and the maximum was US\$ $4,877,777$. Table 1 shows a reduction in mean, median and minimum values of the of TA by $0.1 \%, 0.8 \%$ and $0.7 \%$ respectively. There was also a $2.4 \%$ increase in the maximum value of the TA after the operationalization of the EAC Common Market.

\section{Market Capitalization (MC)}

MC was calculated as total number of outstanding shares, multiplied by the market price per share (Yermack 1996). The descriptive statistics results in Table 1 demonstrate the following statistics for 2008/2009: a mean of MC of US\$ 51, 200, a median of US\$ 68, 000, a standard deviation of 1.54, a minimum of US\$3, 000 and a maximum of US\$ 747, 000. Similarly, in $3013 / 2014$, the mean MC was US\$ 85, 500 and the median was US\$ 85, 700, while the standard deviation, minimum, and maximum values were US\$2, 400, and US\$2,474.100 respectively. Overall, between $2008 / 2009$ and $2013 / 2014$, the mean increased by $13 \%$, the median by $5.5 \%$ and the maximum values of the MC was $18.1 \%$. However, the minimum value of the MC fell by $5.6 \%$ after the operationalization of the EAC Common Market in 2010. 
Volume 3 Issue 7 (June 2021) PP. 127-147 DOI 10.35631/AIJBAF.370011

\section{Spearman's Correlations}

\begin{tabular}{|c|c|c|c|c|c|c|c|c|c|c|c|}
\hline & & Correlatio & Coefficient & & & & & & & & \\
\hline \multirow{10}{*}{ 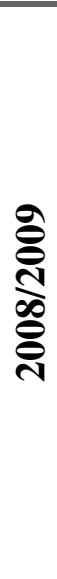 } & & PER & TBQ & ROA & ROE & $\mathrm{BS}$ & GB & $\mathrm{BI}$ & $\mathrm{RM}$ & TA & $\mathrm{MC}$ \\
\hline & PER & 1 & & & & & & & & & \\
\hline & TBQ & $0.571 *$ & 1 & & & & & & & & \\
\hline & ROA & $-0.325 * *$ & 0.156 & 1 & & & & & & & \\
\hline & ROE & $-0.393 * *$ & 0.065 & $0.662 * * *$ & 1 & & & & & & \\
\hline & $\mathrm{BS}$ & $-0.354 * *$ & 0.050 & 0.123 & 0.245 & 1 & & & & & \\
\hline & $\mathrm{BI}$ & 0.094 & -0.038 & 0.010 & $-0.338 *$ & 0.142 & 0.027 & 1 & & & \\
\hline & RM & -0.006 & -0.078 & -0.162 & 0.162 & $0.303^{*}$ & $0.299 *$ & -0.023 & 1 & & \\
\hline & TA & -0.237 & -0.119 & -0.193 & 0.204 & $0.664 * * *$ & $0.526 * * *$ & -0.116 & $0.588 * * *$ & 1 & \\
\hline & $\mathrm{MC}$ & -0.046 & 0.074 & -0.003 & 0.230 & $0.576 * * *$ & $0.408 * *$ & -0.033 & $0.439 * * *$ & $0.818 * * *$ & 1. \\
\hline \multirow{9}{*}{$\frac{\underset{n}{\sigma}}{\underset{\delta}{\sigma}}$} & PER & 1 & & & & & & & & & \\
\hline & TBQ & $0.409 * * *$ & 1 & & & & & & & & \\
\hline & ROE & -0.121 & $0.430 * * *$ & $0.687 * * *$ & 1 & & & & & & \\
\hline & $\mathrm{BS}$ & -0.143 & -0.186 & 0.018 & $0.260 *$ & 1 & & & & & \\
\hline & GB & $-0.288 *$ & -0.244 & -0.087 & -0.033 & $0.450 * * *$ & 1 & & & & \\
\hline & $\mathrm{BI}$ & -0.060 & 0.018 & 0.204 & 0.180 & $0.340 * *$ & 0.055 & 1 & & & \\
\hline & RM & -0.197 & $-0.282^{*}$ & -0.167 & 0.197 & $0.330 * *$ & $0.357 * *$ & $-0.301 *$ & 1. & & \\
\hline & TA & $-0.526 * * *$ & $-0.436 * * *$ & 0.017 & $0.352 * *$ & $0.598 * * *$ & $0.322 * *$ & -0.048 & $0.482 * * *$ & 1 & \\
\hline & $\mathrm{MC}$ & $-0.284^{*}$ & 0.078 & $0.427 * * *$ & $0.637 * * *$ & $0.539 * * *$ & 0.124 & -0.004 & $0.306 * *$ & $0.764 * * *$ & 1 \\
\hline
\end{tabular}

*** Significant at $1 \%$ level, **Significant at $5 \%$ level, $*$ Significant at $10 \%$ level. GB $=$ GB Gender diversity of the board, BI $=$ Board independence, $\mathrm{RM}=$ Enterprise Risk Management, $\mathrm{BS}=$ Board size, $\mathrm{TA}=$ Total assets and $\mathrm{MC}=$ Market capitalization

Source: Own Source

\section{Table 2 Spearmen's Rank Correlation Analysis}


Volume 3 Issue 7 (June 2021) PP. 127-147

DOI 10.35631/AIJBAF.370011

According to the results of the Spearman's rank correlation 2008/2009 in table 4.2 above, the following pair of variables showed significant correlation at $1 \%$ significance: ROA and ROE with correlation coefficient of 0.66 , PER and TBQ with correlation coefficient of $0.57, \mathrm{~GB}$ and TA with correlation coefficient of $0.53, \mathrm{RM}$ and TA with correlation coefficient of $0.44, \mathrm{RM}$ and TA with correlation coefficient of 0.59 , BS and TA with correlation coefficient of 0.66 , BS and TA with correlation coefficient of 0.58 and BS and GB with correlation coefficient of 0.48 . Other pairs of variables that displayed significant correlation at $5 \%$ were: PER and ROA with correlation coefficient of -0.33 , PER and ROE with correlation coefficient of -0.39 , PER and BS with correlation coefficient of -0.35 , ROE and BI with correlation coefficient of -0.34 , GB and TA with correlation coefficient of 0.41 , and TA and MC with correlation coefficient of 0 82. Finally, BS and RM, with correlation coefficient of 0.30 , and GB and RM, with correlation coefficient of 0.30 , were significantly correlated at $10 \%$.

The Spearman's rank correlation for 2013/2014 in Table 2 shows the following pair of variables had a significant correlation at 1\%: PER and TBQ with correlation coefficient of 0.41 , PER and GB with correlation coefficient of -0.29 , PER and TA with correlation coefficient of -0.53 , PER and TA with correlation coefficient of -0.28 , TBQ and ROA with correlation coefficient of 0.60 , TBQ and ROE with correlation coefficient of -0.43 , TBQ and RM with correlation coefficient of -0.28 , TBQ and TA with correlation coefficient of -0.44 , ROA and ROE with correlation coefficient of 0.69 , ROA and MC with correlation coefficient of 0.43 , ROE and BS with correlation coefficient of 0.26 , ROE and TA with correlation coefficient of 0.35 , ROE and MC with correlation coefficient of 0.64 , BS and GB with correlation coefficient of 0.45 , BS and BI with correlation coefficient of 0.34 , BS and RM with correlation coefficient of 0.33 , BS and TA with correlation coefficient of 0.60 , BS and MC with correlation coefficient of 0.54, GB and RM with correlation coefficient of 0.34 , GB and TA with correlation coefficient of 0.32 , BI and RM with correlation coefficient of -0.30 , RM and TA with correlation coefficient of $0.48, \mathrm{RM}$ and $\mathrm{MC}$ with correlation coefficient of 0.31 , and TA and MC with correlation coefficient of 0.76. All the above correlation figures indicate lower correlations between the dependent and independent variables and some lack of significant correlations between some variables which is an indication no Multicollinearity problem between variables.

\section{Ordinary Least Squares Regression (OLS) Results}

This subsection provides the outcome of regressions analysis. According to Bowerman et al., (2003) the independent variable's estimated coefficients indicate the size of effect that one variable has over the dependent variables.

\section{The Influence of Corporate Governance Indicators On the ROA}

Table 3 below, presents a summary of the regression results on the relationship between ROA, and corporate governance indicators and control variables in 2008/2009 and 2013/2014.

Table 3: Regression - Corporate Governance, Control Variables and ROA

\begin{tabular}{|c|c|c|}
\hline \multirow{2}{*}{$\begin{array}{l}\text { Dependent variable: } \\
\text { ROA }\end{array}$} & $2008 / 2009$ & $2013 / 2014$ \\
\hline & $\begin{array}{cl}\text { Model fit: R2 } & =0.2960 \\
\mathrm{P} & =0.1601 \\
\mathrm{~F} & =1.6809\end{array}$ & $\begin{array}{cc}\text { Model fit: R2 } & =0.5426 \\
\mathrm{P} & =0.0003 \\
\mathrm{~F} & =5.8543\end{array}$ \\
\hline
\end{tabular}


Volume 3 Issue 7 (June 2021) PP. 127-147 DOI 10.35631/AIJBAF.370011

\begin{tabular}{|l|l|l|l|l|l|l|}
\hline Independent Variables & Coeff & $\mathrm{T}$ & $\mathrm{P}$ & Coeff & $\mathrm{T}$ & $\mathrm{P}$ \\
\hline Constant & 60.843 & 6.091 & 0.000 & 52.834 & 3.713 & 0.001 \\
\hline GB & -0.086 & -1.392 & 0.174 & 0.025 & 0.206 & 0.838 \\
\hline BI & -0.072 & -1.693 & 0.101 & 0.032 & 0.309 & 0.759 \\
\hline RM & -0.848 & -.470 & 0.642 & -2.574 & -0.504 & 0.618 \\
\hline BS & 0.855 & 1.771 & $0.087 *$ & -0.409 & -0.613 & 0.544 \\
\hline TA & -2.291 & -2.294 & $0.029 * *$ & -3.284 & -2.718 & 0.101 \\
\hline MC & 1.723 & 1.737 & $0.093 *$ & 6.360 & 4.954 & $0.000 * * *$ \\
\hline
\end{tabular}

*** Significant at $1 \%$ level, **Significant at 5\% level, * Significant at $10 \%$ level $\mathrm{GB}=\mathrm{GB}$ Gender diversity of the board, $\mathrm{BI}=$ Board independence, $\mathrm{RM}=$ Enterprise Risk Management, $\mathrm{BS}=$ Board size, $\mathrm{TA}=$ Total assets and $\mathrm{MC}=$ Market capitalization

Source: Own Source

The 2008/2009 results show an adjusted R-squared value of 0.30 , which indicates that about $30 \%$ of the total variability in ROA is explained by GB, BI, RM, BS, TA and MC. The BS had a statistically significant positive influence on ROA $(\mathrm{p}=0.09<0.10)$, hence an increase in BS by one member would result in an increase in the ROA by $86 \%$, holding all independent and control variables constant. The $\mathrm{F}$ test result indicates that all variables in aggregate are not statistically significant in influencing ROA $(F=1.68, \mathrm{p}=0.16>0.10)$. On the other hand, the 2013/2014 results (Table 4.3), show an adjusted R-squared value of 0.54 , which indicates a better model fit than in 2008/2009. This means that, about $54 \%$ of the total variability in ROA is explained by GB, BI, RM, BS, TA and MC. The F test result for the regression model in $2013 / 2014$ indicates that all variables in aggregate have a statistically significant influence on ROA $(F=5.85, p=0.00<0.01)$. This suggests that the corporate governance indicators and the control variables, are more relevant to ROA in 2013/2014 than in 2008/2009. The estimated coefficient for BS in 2008/2009 suggests that an additional director on the board contributes $86 \%$ to ROA, holding other variables constant. On the contrary, the contribution from an additional director on the board in 2013/2014 diminishes ROA by $41 \%$, although this impact was not statistically significant.

The Influence of Corporate Governance On The ROE

Table 4 below, presents a summary of the regression results on the relationship between ROE, as the dependent variable, and corporate governance indicators and control variables in 2008/2009 and 2013/2014.

Table 4. Regression - Corporate Governance, Control Variables and ROE

\begin{tabular}{llc} 
Dependent variable: ROE & $\mathbf{2 0 0 8 / 2 0 0 9}$ & $\mathbf{2 0 1 3 / 2 0 1 4}$ \\
\cline { 2 - 3 } & Model fit: $\mathrm{R} 2=0.2121$ & Model fit: $\mathrm{R} 2=0.5168$ \\
$\mathrm{P}=0.0997$ & $\mathrm{P}=0.0001$ \\
$\mathrm{~F}=1.9820$ & $\mathrm{~F}=6.3576$
\end{tabular}

\begin{tabular}{lllllll}
\hline Independent Variables & Coeff & $\mathrm{T}$ & $\mathrm{P}$ & Coeff & $\mathrm{T}$ & $\mathrm{P}$ \\
\hline Constant & 62.223 & 2.924 & 0.007 & 26.876 & 1.411 & 0.167 \\
\hline GB & 0.045 & 0.248 & 0.806 & -0.048 & -0.292 & 0.772 \\
\hline BI & -0.245 & -2.069 & $0.047^{* *}$ & 0.105 & 0.712 & 0.481 \\
\hline RM & 0.424 & 0.102 & 0.919 & 2.336 & 0.402 & 0.690 \\
\hline
\end{tabular}


Volume 3 Issue 7 (June 2021) PP. 127-147

DOI 10.35631/AIJBAF.370011

\begin{tabular}{lllllll}
\hline BS & 1.467 & 1.598 & 0.120 & -0.578 & -0.709 & 0.483 \\
\hline TA & -1.931 & -0.929 & 0.360 & -1.530 & -0.986 & 0.331 \\
\hline MC & 1.947 & 1.082 & 0.288 & 6.471 & 4.239 & $0.000 * * *$
\end{tabular}

*** Significant at $1 \%$ level, **Significant at 5\% level, * Significant at $10 \%$ level

$\mathrm{GB}=\mathrm{GB}$ Gender diversity of the board, $\mathrm{BI}=$ Board independence, $\mathrm{RM}=$ Enterprise Risk

Management, $\mathrm{BS}=$ Board size, $\mathrm{TA}=$ Total assets and $\mathrm{MC}=$ Market capitalization

Source: Own Source

As shown in Table 4 above, in 2008/2009, the OLS regression results showed an adjusted Rsquared value of 0.21 , which suggests that about $21 \%$ of the total variability in ROE is explained by GB, BI, RM, BS and MC. The F test result indicated that all variables jointly influence $\operatorname{ROE}(\mathrm{F}=1.98, \mathrm{p}=0.09<0.10)$. BI had a statistically significant negative influence on ROE ( $\mathrm{p}=0.05<0.10)$, hence, an increase in BI by one percent would result in a decrease in the ROE of $25 \%$, holding other independent and control variables constant. On the other hand, the results for 2013/2014 (Table 4.4) presented an adjusted R-squared value of 0.52, which shows a better model fit than 2008/2009. The adjusted R-squared results indicates that during $2013 / 2014$, about $52 \%$ of the total variability in ROE could be attributed to GB, BI, RM, BS, $\mathrm{TA}$, and MC. The F test result also indicated that all variables jointly influenced $\mathrm{ROE}(\mathrm{F}=6.34$, $\mathrm{p}=0.00<0.01)$. Although the MC (a control variable) is the only variable that had a statistically significant positive influence on ROE ( $\mathrm{p}=0.00<0.01$ ) in 2013/2014, the adjusted R-squared suggests that the corporate governance indicators, together with the control variables, have more relevance in explaining ROE in 2013/2014 than in 2008/2009.

\section{The Influence of Corporate Governance On TBQ}

The TBQ is calculated as the ratio of company market value to the total book value (Bhagat \& Jefferis 2005). Table 5, below, presents a summary of the regression results on the relationship between TBQ, as the dependent variable, and corporate governance indicators and control variables in 2008/2009 and 2013/2014.

Table 5: Regression - Corporate Governance, Control Variables and TBQ

\begin{tabular}{|c|c|c|c|c|c|c|}
\hline \multirow{2}{*}{$\begin{array}{l}\text { variable: TBQ } \\
\text { Independent Variables }\end{array}$} & \multicolumn{3}{|c|}{$\begin{array}{l}\text { 2008/2009 } \\
\text { Model fit: } \mathrm{R} 2=0.2088 \\
\quad \mathrm{P}=0.2719 \\
\mathrm{~F}=1.3368\end{array}$} & \multicolumn{3}{|c|}{$\begin{array}{l}\mathbf{2 0 1 3} / \mathbf{2 0 1 4} \\
\text { Model fit; } \mathrm{R} 2=0.7368 \\
\quad \mathrm{P}=0.0000 \\
\mathrm{~F}=8.6757\end{array}$} \\
\hline & Coeff & $\mathrm{T}$ & $\mathrm{P}$ & Coeff & $\mathrm{T}$ & $\mathrm{P}$ \\
\hline Constant & 2.129 & 1.347 & 0.188 & 5.751 & 4.840 & 0.000 \\
\hline GB & -0.004 & -0.259 & 0.798 & 0.002 & 0.181 & 0.858 \\
\hline $\mathrm{BI}$ & -0.011 & -1.331 & 0.193 & -0.001 & -0.169 & 0.867 \\
\hline $\mathrm{RM}$ & 0.005 & 0.013 & 0.990 & 0.126 & 0.216 & 0.830 \\
\hline $\mathrm{BS}$ & 0.098 & 1.218 & 0.233 & 0.007 & 0.126 & 0.901 \\
\hline TA & -0.332 & -2.294 & $0.029 * *$ & -0.842 & -6.749 & $0.000 * * *$ \\
\hline $\mathrm{MC}$ & 0.268 & 1.526 & 0.138 & 0.827 & 6.801 & $0.000 * * *$ \\
\hline
\end{tabular}

*** Significant at $1 \%$ level, **Significant at 5\% level, * Significant at $10 \%$ level

$\mathrm{GB}=\mathrm{GB}$ Gender diversity of the board, $\mathrm{BI}=$ Board independence, $\mathrm{RM}=$ Enterprise Risk

Management, $\mathrm{BS}=$ Board size, $\mathrm{TA}=$ Total assets and $\mathrm{MC}=$ Market capitalization 
According to the OLS regression results in Table 5, the adjusted R-squared value in 2008/2009 was 0.21 , which suggests that about $21 \%$ of the total variability in TBQ can be explained by $\mathrm{GB}, \mathrm{BI}, \mathrm{RM}, \mathrm{BS}, \mathrm{TA}$ and MC. The $\mathrm{F}$ test result indicated that all variables in aggregate do not have a statistically significant influence on TBQ in 2008/2009 ( $F=1.34, p=0.27>0.10)$. The 2013/2014 results (Table 5), shows an adjusted R-squared value of 0.74 , which demonstrates a better model fit, than 2008/2009. In other words, in 2013/2014 about $74 \%$ of the total variability in TBQ can be explained by GB, BI, RM, BS, TA, and MC. The F test result also indicated that all variables in aggregate have a statistically significant influence on TBQ $(\mathrm{F}=$ $8.68, \mathrm{p}=0.00<0.01)$. This improvement in the model fit and model significance suggests that corporate governance indicators, together with the control variables, have more relevance in explaining TBQ in 2013/2014 than in 2008/2009.

\section{The Influence of Corporate Governance On PER}

Table 6 below, presents a summary of the regression results on the relationship between PER, as the dependent variable, and corporate governance indicators and control variables in 2008/2009 and 2013/2014.

Table 6: Regression - Corporate Governance, Control Variables and PER

\begin{tabular}{|c|c|c|c|c|c|c|}
\hline \multirow[t]{2}{*}{ Dependent variable: PER } & \multicolumn{3}{|l|}{2009} & \multicolumn{3}{|l|}{2014} \\
\hline & \multicolumn{3}{|c|}{$\begin{array}{l}\text { Model fit: } \mathrm{R} 2=0.1834 \\
\quad \mathrm{P}=0.2402 \\
\mathrm{~F}=1.4186\end{array}$} & \multicolumn{3}{|c|}{$\begin{array}{l}\text { Model fit; } \mathrm{R} 2=0.4099 \\
\qquad \mathrm{P}=0.0038 \\
\mathrm{~F}=3.9907\end{array}$} \\
\hline Independent Variables & Coeff & $\mathrm{T}$ & $\mathrm{P}$ & Coeff & $\mathrm{T}$ & $\mathrm{P}$ \\
\hline Constant & 3.921 & 3.312 & 0.002 & 52.824 & 3.713 & 0.000 \\
\hline GB & 0.003 & 0.220 & 0.828 & 0.025 & 0.206 & 0.152 \\
\hline BI & 0.004 & 0.473 & 0.640 & 0.032 & 0.309 & 0.236 \\
\hline $\mathrm{RM}$ & 0.269 & 0.888 & 0.382 & -2.574 & -0.504 & 0.291 \\
\hline $\mathrm{BS}$ & -0.096 & -1.258 & 0.218 & -0.409 & -0.613 & $0.032 * *$ \\
\hline TA & -0.161 & -1.437 & 0.161 & -0.284 & -2.718 & $0.002 * * *$ \\
\hline $\mathrm{MC}$ & 0.199 & 1.711 & $0.097 *$ & 6.360 & 4.954 & 0.500 \\
\hline
\end{tabular}

*** Significant at $1 \%$ level, **Significant at 5\% level, * Significant at $10 \%$ level

$\mathrm{GB}=\mathrm{GB}$ Gender diversity of the board, $\mathrm{BI}=$ Board independence, $\mathrm{RM}=$ Enterprise Risk Management, $\mathrm{BS}=$ Board size, $\mathrm{TA}=$ Total assets and $\mathrm{MC}=$ Market Capitalization

Source: Own Source

The 2008/2009 results (Table 4.6) show an adjusted R-squared value of 0.18, which means that during 2008/2009, about $18 \%$ of the total variability in PER is explained by GB, BI, RM, BS, $\mathrm{TA}$ and $\mathrm{MC}$. The $\mathrm{F}$ test result indicates that all variables in aggregate do not have a statistically significant influence on PER ( $F=1.42, p=0.24>0.10$ ). According to the 2013/2014 results (Table 4.6), the adjusted R-squared value was 0.41 , which indicates a better model fit than 2008/2009. This shows that about $41 \%$ of the total variability in PER in 2013/2014 can be explained by GB, BI, RM, and BS, TA and MC. The F test results also indicates that all variables in aggregate have a statistically significant influence on PER $(F=3.99, p=0.00)$. BS had a statistically significant negative influence on PER $(\mathrm{p}=0.03<0.05)$ suggesting that an 
Volume 3 Issue 7 (June 2021) PP. 127-147

DOI 10.35631/AIJBAF.370011

increase in BS by one member would result in a decrease in PER by $40.9 \%$, holding all independent and control variables constant. The composite of PER (price per share and earning per share) offers two possible explanations for this negative relationship between PER and BS; either earning per share increases as BS increases, or price per share deceases as BS increases. The negative, though not statistically significant, relationship between ROA and BS in 2013/2014 (in Table 4.3 under Section 5.5.1) indicates that the former (negative relationship between price per share and BS) offers an appropriate explanation for the negative relationship between BS and PER. This implies that the EAC markets in 2013/2014 tended to react positively to smaller BS and negatively to larger BS. In inverting the logarithm transformation of the dependent variable from PER to PER, the impact of this market reaction could be translated as evidence that the addition of one director would bring about approximately $33.5 \%$ decrease in the PER and vice versa.

\section{Control Variables}

As mentioned in Section 3.4, TA and MC were used as control variables in the regression models, in order to statistically adjust their effects on company financial performance and thereby estimate the effects of corporate governance indicators on this outcome variable. Weobserved some significant relationships between the control variables and the EAC's listed companies' financial performance indicators. For example, in 2008/2009 (Table 4.3), the TA had a statistically significant negative influence on ROA $(\mathrm{p}=0.03<0.05)$ while the MC had a statistically significant positive influence on ROA $(\mathrm{p}=0.09<0.10)$. However, in 2013/2014 (Table 4.3), only the MC had a statistically significant positive influence on ROA $(\mathrm{p}=0.00<0.01)$. Furthermore, no control variable significantly influenced ROE in 2008/2009. However, in 2013/2014 (Table 4.4), the MC had a statistically significant positive influence on ROE ( $\mathrm{p}=0.00<0.01$ ). In 2008/2009 (Table 5), the TA had a statistically significant negative influence on TBQ ( $\mathrm{p}=0.03<0.05)$. However, in 2013/2014 (Table 5), the MC had a statistically significant positive influence on TBQ $(\mathrm{p}=0.00<0.01)$ while the TA had a statistically significant negative influence on TBQ $(\mathrm{p}=0.00<0.01)$. Furthermore, according to the results in Table 6 the MC had a statistically significant positive influence on PER $(\mathrm{p}=0.09<0.10)$. The TA also had a statistically significant negative influence on PER $(p=0.00<0.01)$.

\section{Summary of The Hypothesis Test Results}

Table 7, below, presents the summary of the hypothesis tests results for the five hypotheses used in this study.

\begin{tabular}{|l|l|l|}
$\begin{array}{l}\text { Study } \\
\text { hypothesizes }\end{array}$ & Tests results & $\begin{array}{l}\text { H5 There has been a significant change in } \\
\text { corporate governance indicators following } \\
\text { the operationalization of the EAC- Common } \\
\text { Market }\end{array}$ \\
\cline { 2 - 4 } & &
\end{tabular}

H1: There is a significant relationship between board independence and company financial performance

\begin{tabular}{c|c|c|c} 
GB and ROA & Unsupported & Unsupported & Unsupported \\
\hline GB and ROE & Unsupported & Unsupported & Unsupported \\
\hline GB and TBQ & Unsupported & Unsupported & Unsupported \\
\hline GB and PER & Unsupported & Unsupported & Unsupported
\end{tabular}

Copyright (C) GLOBAL ACADEMIC EXCELLENCE (M) SDN BHD - All rights reserved 
Volume 3 Issue 7 (June 2021) PP. 127-147

DOI 10.35631/AIJBAF.370011

$\mathrm{H} 2$ : There is a significant relationship between board independence and company financial performance

\begin{tabular}{|l|l|l|l}
\hline BI and ROA & Unsupported & Unsupported & Unsupported \\
\hline BI and ROE & Supported & Unsupported & Inconclusive \\
\hline BI and TBQ & Unsupported & Unsupported & Unsupported \\
\hline BI and PER & Unsupported & Unsupported & Unsupported
\end{tabular}

H3: There is a significant relationship between company commitment to enterprise risk management and its financial performance.

\begin{tabular}{l|l|l|l} 
RM and ROA & Unsupported & Unsupported & Unsupported \\
\hline RM and ROE & Unsupported & Unsupported & Unsupported \\
\hline RM and TBQ & Unsupported & Unsupported & Unsupported \\
\hline RM and PER & Unsupported & Unsupported & Unsupported
\end{tabular}

H4: There is a significant relationship between the board size and the company financial performance

\begin{tabular}{l|l|l|l} 
BS and ROA & Unsupported & Supported & Inconclusive \\
\hline BS and ROE & Unsupported & Unsupported & Unsupported \\
\hline BS and TBQ & Unsupported & Unsupported & Unsupported \\
\hline BS and PER & Unsupported & Supported & Inconclusive
\end{tabular}

$\mathrm{GB}=\mathrm{GB}$ of the Board, $\mathrm{BI}=\mathrm{Board}$ Independence, $\mathrm{RM}=$ Enterprise Risk Management, and BS $=$ Board Size.

Source: Own Source

Table 7 indicates that there were inconclusive results about the relationships between BI and ROA, BS and ROA, and BS and PER. However, no hypotheses on the relationships between corporate governance indicators and company financial performance (ROA, ROE, TBQ and PER) were supported.

\section{Limitations Of The Study}

A number of limitations were identified in this study. First, the study used a sample of fortytwo companies that were listed on the stock exchange during the study period. However, most companies in Rwanda, Tanzania and Uganda were listed on the security market until after 2010 and hence did not qualify to be included in the sample. Secondly, the current study used financial data from listed companies only, which means that private companies and other small and medium enterprises were not considered, although they are also affected by corporate governance (Chiloane et al., 2014). Thirdly, financial data was extracted from private databases (DataStream and Eikon), and most companies whose data was missing were left out of this study. Fourthly, the study used some specific accounting-based and market-based performance measures whose selection was based on previous research. Using different performance measures could possibly result in different results. We recommend that further studies be carried out on corporate governance within the EAC, and that such studies cover more aspects of the topic, since this study did not exhaustively cover all areas of corporate governance and company performance within the EAC. In particular, we suggest that future researchers consider carrying out a similar study using data from un-listed companies, SME's, or adopt different financial and non- financial performance indicators to test the influence of corporate governance. It would also be worthwhile for future researchers to expand the scope of this 
Volume 3 Issue 7 (June 2021) PP. 127-147

DOI 10.35631/AIJBAF.370011

study and cover elements of corporate governance that are not covered in this study, such as duality of CEO's, conduct of board meetings and directors' qualifications, so as to provide a broader understanding of the nature of the relationship between corporate governance and company performance in the EAC.

\section{Conclusion}

Our findings did not support hypotheses $\mathrm{H} 1$ and $\mathrm{H} 3$ while $\mathrm{H} 2$ and $\mathrm{H} 4$ and $\mathrm{H} 5$ were inconclusive. The study's outcomes indicated that gender diversity of the board (H1) had no statistically significant influence on company financial performance indicators measured by ROA, ROE, TBQ and PER. The relationship between board independence (H2) and company financial performance was inconclusive, while the regression results also revealed no significant relationship between enterprise risk management $(\mathrm{H} 3)$ and company financial performance measured by ROA, ROE, TBQ and PER. The study also discovered that the majority of companies within the EAC did not implement enterprise risk management, which might have been due to the high costs associated with its implementation (Kerstin et al., 2014). The regression results on the board size (H4) and company performance revealed inconclusive results. Finally, the result of the hypothesis H5 about changes in corporate governance indicators before (2008/2009) and after (2013/2014) the operationalization of the EACCommon market indicated inconclusive results. We thus recommend that EAC-listed companies adopt a code of best practice that emphasizes an increase, rather than a decrease, in board independence to improve board advisory and monitoring functions which may have a positive contribution to company financial performance (Raheja 2005). Secondly, the study advocate that EAC-listed companies should have an optimal board size not more than nine members to avoid the disadvantage of large boards (Lipton and Lorsch 1992).

\section{References}

Adams, R, Hermalin, BE \& Weisbach, MS 2008, The role of boards of directors in corporate governance: A conceptual framework and survey, National Bureau of Economic Research.

Alagha, HS 2016, 'Corporate Governance Practices and Firm Performance of Listed Companies Including Islamic Financial Institutions in the United Arab Emirates', Victoria University.

Anderson, RC \& Reeb, DM 2003, 'Founding-family ownership and firm performance: evidence from the S\&P 500', The Journal of Finance, vol. 58, no. 3, pp. 1301-28.

Beasley, MS 1996, 'An empirical analysis of the relation between the board of director composition and financial statement fraud', Accounting Review, vol. 71, no. 4, pp. 44365.

Berglof, E \& Claessens, S 2004, 'Enforcement and corporate governance', World Bank Policy Research Working Paper, no. 3409.

Bhaduri, SN \& Selarka, E 2016, 'Corporate Governance: An Overview', in Corporate Governance and Corporate Social Responsibility of Indian Companies, Springer, pp. 61-72.

Bhagat, S \& Jefferis, RH 2005, The econometrics of corporate governance studies, Mit Press.

Bowerman, BL, O'Connell, RT, Murphree, E, Huchendorf, SC \& Porter, DC 2003, Business statistics in practice, McGraw-Hill/Irwin New York.

Broadbridge, A, Hearn, J, Huse, M \& Grethe Solberg, A 2006, 'Gender-related boardroom dynamics: How Scandinavian women make and can make contributions on corporate boards', Women in Management Review, vol. 21, no. 2, pp. 113-30.

Copyright $\odot$ GLOBAL ACADEMIC EXCELLENCE (M) SDN BHD - All rights reserved 
Volume 3 Issue 7 (June 2021) PP. 127-147

DOI 10.35631/AIJBAF.370011

Brownbridge, M 2002, 'Resolving bank failures in Uganda: Policy lessons from recent bank failures', Development Policy Review, vol. 20, no. 3, pp. 279-91.

Cheserek, BK 2007, 'The determinants of bank failures: a survey of commercial banks in Kenya', University of Nairobi.

Chiloane-Tsoka, E \& Rasivetshele, AM 2014, 'Corporate social responsibility: A toolkit for SMEs efficiency in Tshwane, South Africa', Problems and Perspectives in Management, vol. 12, no. 4, pp. 276-82

Chorafas, DN 2004, The Management of Equity Investments, Butterworth-Heinemann.

CMA, K 2002, 'Guidelines on Corporate Governance in public listed Companies in Kenya', Kenya Gazette Notice No. 369, 122, vol. 128.

CMA, U 2003, The capital markets corporate governance guidelines; Uganda, viewed 18 December 2014 <http://www.cmauganda.co.ug/files/downloads/Corporate\%20Gonance\%20Guideline s.pdf $>$.

Collis, J \& Hussey, R 2013, Business research: A practical guide for undergraduate and postgraduate students, Palgrave macmillan.

Conyon, MJ \& Peck, SI 1998, 'Board size and corporate performance: evidence from European countries', The European Journal of Finance, vol. 4, no. 3, pp. 291-304.

Eisenberg, T 2005, 'Larger board size and decreasing firm value in small firms', Journal of Financial economics, vol. 48, no. 1, pp. 35-54.

Fama, EF \& Jensen, MC 1983, 'Agency Problems and Residual Claims', Journal of Law \& Economics, vol. 26, no. 2, pp. 327-49.

Ford, RC \& Richardson, WD 1994, 'Ethical Decision-Making - a Review of the Empirical Literature', Journal of Business Ethics, vol. 13, no. 3, pp. 205-21.

Friedman, M 2007, The social responsibility of business is to increase its profits, Springer.

Gordon, LA, Loeb, MP \& Tseng, CY 2009, 'Enterprise risk management and firm performance: A contingency perspective', Journal of accounting and public policy, vol. 28, no. 4, pp.01-27.

Grace, MF, Leverty, JT, Phillips, RD \& Shimpi, P 2015, 'The Value of Investing in Enterprise Risk Management', Journal of risk and insurance, vol. 82, no. 2, pp. 289-316.

Grant, P \& McGhee, P 2014, 'Corporate governance reform: character-building structures', Business Ethics-a European Review, vol. 23, no. 2, pp. 125-38.

Heenetigala, K 2011, 'Corporate governance practices and firm performance of listed companies in Sri Lanka', Victoria University Melbourne.

Hoyt, RE \& Liebenberg, AP 2011, 'The Value of Enterprise Risk Management', Journal of risk and insurance, vol. 78, no. 4, pp. 795-822.

Jensen, MC 1993, 'The Modern Industrial-Revolution, Exit, and the Failure of Internal ControlSystems', Journal of Finance, vol. 48, no. 3, pp. 831-80.

Jensen, MC \& Meckling, WJ 1976, 'Theory of the firm: Managerial behavior, agency costs, and ownership structure'.

Kaplan, RS \& Norton, DP 1996, The balanced scorecard: translating strategy into action, Harvard Business Press.

Kerstin, D, Simone, O \& Nicole, Z 2014, 'Challenges in implementing enterprise risk management', ACRN Journal of Finance and Risk Perspectives, vol. 3, no. 3, pp. 1-14.

Khan, WA \& Vieito, JP 2013, 'Ceo gender and firm performance', Journal of Economics and Business, vol. 67, pp. 55-66.

Klein, A 1998, 'Firm Performance and Board Committee Structure 1', The Journal of Law and Economics, vol. 41, no. 1, pp. 275-304.

Copyright $\odot$ GLOBAL ACADEMIC EXCELLENCE (M) SDN BHD - All rights reserved 
Volume 3 Issue 7 (June 2021) PP. 127-147

DOI 10.35631/AIJBAF.370011

Konrad, AM, Kramer, V \& Erkut, S 2008, 'Critical mass: The impact of three or more women on corporate boards', Organizational dynamics, vol. 37, no. 2, pp. 145-64.

Liebenberg, AP \& Hoyt, RE 2003, 'The determinants of enterprise risk management: Evidence from the appointment of chief risk officers', Risk Management and Insurance Review, vol. 6, no. 1, pp. 37-52.

Lipton, M \& Lorsch, JW 1992, 'A Modest Proposal for Improved Corporate Governance', Business Lawyer, vol. 48, no. 1, pp. 59-77.

Lundqvist, SA 2015, 'Why firms implement risk governance - Stepping beyond traditional risk management to enterprise risk management', Journal of accounting and public policy, vol. 34, no. 5, pp. 441-66.

McGrath, SK \& Whitty, SJ 2015, 'Redefining governance: from confusion to certainty and clarity', International Journal of Managing Projects in Business, vol. 8, no. 4, pp. 75587.

Munisi, G \& Randoy, T 2013, 'Corporate governance and company performance across SubSaharan African countries', Journal of Economics and Business, vol. 70, pp. 92-110.

Muriithi, P 2009, 'Corporate Governance', KASNEB Newsline, no. 1, January to March, p. 3.

Nguyen, P, Rahman, N, Tong, A \& Zhao, R 2015, 'Board size and firm value: evidence from Australia', Journal of Management \& Governance, vol. 20, no. 4, pp. 851-73.

Ngwenya, S \& Khumalo, M 2012, 'CEO compensation and performance of state owned enterprises in South Africa', Corporate Ownership and Control, vol. 10, no. 1 A, pp. 97 109.

Niessen, A \& Ruenzi, S 2006, 'Sex matters: Gender and mutual funds', manuscript, University of Cologne.

Nocco, BW \& Stulz, RM 2006, 'Enterprise risk management: theory and practice', Journal of applied corporate finance, vol. 18, no. 4, pp. 8-20.

Okiro, K 2014, 'Corporate governance, capital structure, regulatory compliance and performance of firms listed at the East African community securities exchange', University of Nairobi.

Pagach, D \& Warr, R 2011, 'The Characteristics of Firms That Hire Chief Risk Officers', Journal of risk and insurance, vol. 78, no. 1, pp. 185-211.

Pathan, S, Skully, M \& Wickramanayake, J 2007, 'Board size, independence and performance: an analysis of Thai banks', Asia-Pacific Financial Markets, vol. 14, no. 3, pp. 211-27.

Prinsloo, C 2013, The East African Community - the conducive environment, successes \& challenges for integration., <http://www.afdb.org/en/aec-2013/papers/paper/the-eastafrican-community-the-conducive-environment-successes-challenges-for-regionalinte $>$.

Rossouw, GJ 2005, 'Business Ethics and Corporate Governance in Africa', Business \& society, vol. 44, no. 1, pp. 94-106.

Shleifer, A \& Vishny, RW 1997, 'A survey of corporate governance', Journal of Finance, vol. 52, no. 2, pp. 737-83.

Vandegrift, D \& Brown, P 2005, 'Gender differences in the use of high-variance strategies in tournament competition', The Journal of Socio-Economics, vol. 34, no. 6, pp. 834-49.

Veal, AJ 2005, Business research methods : a managerial approach / A.J. Veal, South Melbourne : Pearson Addison Wesley, 2005 2nd ed.

Waduge, DSLCS 2011, 'Governance and performance: an empirical study of Australian universities', Victoria University.

Woods, M 2007, 'Linking risk management to strategic controls: a case study of Tesco plc', International Journal of Risk Assessment and Management, vol. 7, no. 8, pp. 1074-88. 
Volume 3 Issue 7 (June 2021) PP. 127-147 DOI 10.35631/AIJBAF.370011

Yabara, M 2012, 'Capital market integration: progress ahead of the east african community monetary union', IMF Working Paper, no. 12/18.

Yermack, D 1996, 'Higher market valuation of companies with a small board of directors', Journal of Financial economics, vol. 40, no. 2, pp. 185-211.

Zeitoun, H \& Pamini, P 2015, 'Corporate Ownership Structure and Top Executives' Prosocial Preferences: The Role of Relational and External Blockholders', Corporate Governance-an International Review, vol. 23, no. 6, pp. 489-503.

Zikmund, W, Babin, B, Carr, J \& Griffin, M 2012, Business research methods, Cengage Learning. 